$\xi=-1$

\title{
An Assessment of Coastal Vulnerability of Pahang's Coast Due to Sea Level Rise
}

\author{
Fazly Amri Mohd ${ }^{1}$, Khairul Nizam Abdul Maulud ${ }^{1 \& 2^{*}}$, Othman A. Karim ${ }^{1}$, Rawshan Ara Begum ${ }^{3}$, Md Firoz Khan $^{4}$, \\ Wan Shafrina Wan Mohd Jaafar ${ }^{2}$, Sharifah Mastura Syed Abdullah', Mohd Ekhwan Toriman ${ }^{5}$, Mohd Khairul \\ Amri Kamarudin', Muhammad Barzani Gasim6, Noorjima Abd Wahab ${ }^{6}$ \\ ${ }^{I}$ Department of Civil and Structural Engineering, Faculty of Engineering and Built Environment, Universiti Kebangsaan Malaysia, \\ 43600 UKM Bangi, Selangor, Malaysia \\ ${ }^{2}$ Earth Observation Centre, Institute of Climate Change, Universiti Kebangsaan Malaysia, 43600 UKM Bangi, Selangor, Malaysia \\ ${ }^{3}$ Center for Water Cycle, Marine Environment and Disaster Management (CWMD), Kumamoto University, 2-39-1 Kurokami, Chuo-ku, \\ Kumamoto 860-8555, Japan \\ ${ }^{4}$ Centre for Tropical Climate Change System, Institute of Climate Change, Universiti Kebangsaan Malaysia, 43600 Bangi, Selangor, \\ Malaysia \\ ${ }^{5}$ Faculty of Social Sciences and Humanities, Universiti Kebangsaan Malaysia, 43600 Bangi, Selangor, Malaysia \\ ${ }^{6}$ East Coast Environmental Research Institute (ESERI), Universiti Sultan Zainal Abidin, Gong Badak Campus, 21300 Kuala Nerus, Ter- \\ engganu, Malaysia \\ *Corresponding authorE-mail: knam@ukm.edu.my
}

\begin{abstract}
Climate change interacts in a different way with varieties of human activities and other drivers of change along coastlines. Sea level rise (SLR) is one of the major impacts of global warming. Changes in climate extremes and SLR may impact the critical infrastructures such as coastal road, jetty and chalets as well as the local community. The population and assets exposed to coastal risks will increase significantly due to population growth, economic development and urbanization in the future. As most of the cities in Malaysia are situated near the coast, immediate actions are needed to minimize the undesired outcome due to the SLR. The main objective of this study is to identify physical variables that may have impacts on the coastal area, thus develop a coastal vulnerability index (CVI) for the East Coast of Peninsular Malaysia. Seven (7) physical variables have been identified to assess the CVI that consists of geomorphology, coastal slope, shoreline change rate, mean significant wave height, mean tidal range, relative sea level rate and land use. A comprehensive CVI was obtained by integrating the differential weighted rank values of the variables. The outcome of this study is useful as a tool for coastal disaster management.
\end{abstract}

Keywords: SLR; CVI; physical variables; climate change.

\section{Introduction}

Coastal zone has increasing importance for their ecological, natural values with high habitat and biological diversity in order to sustain coastal processes and ecosystem services. However, these areas are relatively dynamic and have complex multi-function systems. Studies by [1-2] showed that a wide number conflict between human socio-economic activities. This includes urbanization, tourism and recreational activities, industrial production, energy production and delivering, port activities, shipping, and agriculture. Climate change is being understood as seasonal change and has caused many negative impacts on the livings. The Intergovernmental Panel on Climate Change (IPCC) has indicated that natural environment and human society will be extremely affected by global climate change in particular coastal zones [3]. A study by [1] reported that the coastal inundation due to storm waves, tsunamis and sea level rise may cause serious impact to the coastal zone.

A recent study by [4] showed that SLR is an important issue due to climate change. This introduces that threat to human activities particularly in Deltas and low lying coastal areas. In addition, SLR brings serious impacts to the highly concentrated populated area along the coastal zones [5-6]. Many of the coastal area in Peninsular Malaysia are located in low lying that will be affected by SLR. At present many indicators for measuring the vulnerability of any environment system for example, the coastal system [7-8]. However, literatures showed that CVI has still not been comprehensively studied at the east coast of Peninsular Malaysia. Therefore, the aim of this study is to identify the suitable parameters. These parameters play an important role in addressing the issue due to erosion and inundation. CVI results can be presented as risk maps. The CVI information will be made available to the stakeholder and relevance of practices for planning purpose.

Table 1. An example of coastal vulnerability variables used by the researchers in their studies.

\begin{tabular}{|c|c|c|}
\hline CVI Index by & $\begin{array}{c}\text { Study } \\
\text { Area }\end{array}$ & Variables \\
\hline $\begin{array}{c}\text { Coastal Vulnerability Index } \\
\text { (CVI) [2] }\end{array}$ & USA & $\begin{array}{c}\text { Relief } \\
\text { Rock type } \\
\text { Landform } \\
\text { Relative sea level change }\end{array}$ \\
\hline
\end{tabular}

Copyright $\odot 2018$ Authors. This is an open access article distributed under the Creative Commons Attribution License, which permits unrestricted use, distribution, and reproduction in any medium, provided the original work is properly cited. 


\begin{tabular}{|c|c|c|}
\hline & & $\begin{array}{c}\text { Shoreline displacement } \\
\text { Tidal range } \\
\text { Maximum wave height }\end{array}$ \\
\hline $\begin{array}{c}\text { Coastal Vulnerability Index } \\
\text { (CVI) [11] }\end{array}$ & Geomorphology \\
& $\begin{array}{c}\text { Shoreline erosion and } \\
\text { accretion } \\
\text { Coastal slope } \\
\text { Relative sea level change } \\
\text { Mean wave height } \\
\text { Mean tidal range }\end{array}$ \\
\hline
\end{tabular}

\section{Description of Study Area}

The study area is situated along the coast of Pahang in the eastern region of Peninsular Malaysia facing the South China Sea. This area is located between latitude $4^{\circ} 07^{\prime} 38.39^{\prime \prime}$ and $3^{\circ} 32^{\prime} 5.25^{\prime \prime}$ East, and longitude $103^{\circ} 23^{\prime} 44.68^{\prime \prime}$ and $103^{\circ} 27^{\prime} 41.08^{\prime \prime}$ North as shown in Figure 1. The shoreline is approximately $83.91 \mathrm{~km}$ long from Cherating to Pekan. Sand materials make up the entire of the shoreline. The climate of the study area has been influenced by the Northeast monsoon that begins in early November until ends of March. During this season, the flow of wind over eastern Peninsular Malaysia may reach 30 knots [12]. The yearly temperature varies between $25.6{ }^{\circ} \mathrm{C}$ to $27.8{ }^{\circ} \mathrm{C}$ and this region is subjected to diurnal tides which vary between $1 \mathrm{~m}$ and $2 \mathrm{~m}$, and the mean wave height is about less than $1.8 \mathrm{~m} \mathrm{[13].}$

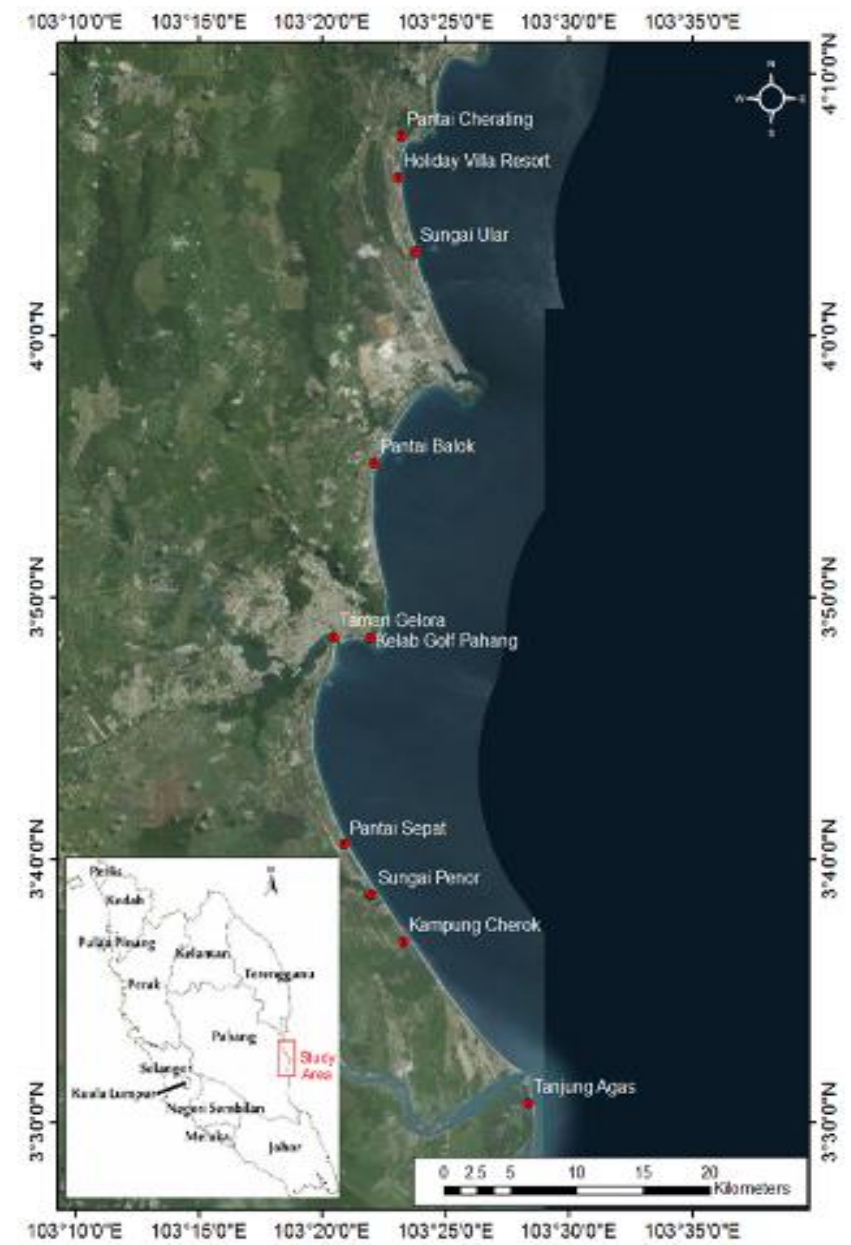

Fig. 1: The study area from Pantai Cherating to Tanjung Agas.

\section{Methodology}

The objective of the CVI is to recognize which areas along the coastal zone will be vulnerable to changes and thus the response from this study will be provided information to government and policy makers to make the best right response for the area in the future. This method was applied in order to evaluate coastal change with the natural variable and also the dominant variables along the coasts. The first stage in developing a CVI is to recognize the main variables that will contribute to coastal vulnerability [9]. There are six variables used by [10-11] which are categorized into geologic and physical variables. The geologic variables consist of geomorphology, shoreline erosion and coastal slope. Meanwhile, the physical variables include mean tidal range, mean significant wave height and relative sea level rate.

Subsequently, the second stage involves relating these variables into the measurable method. A comprehensive CVI was calculated by integrating the differential weighted rank values of the variables. Each of CVI variable was identified by a weighted score in related with its significance and relevance in determining the vulnerability of coastal areas to erosion. By assigning each variable to values ranging from 1 to 5 , where 1 is the lowest risk and 5 represents the highest risk. After assigning the vulnerability value, the CVI value is calculated as the square root of the ranked variables divided by the total number of variables [10] as shown in Equation (1).

$\mathrm{CVI}=\sqrt{\frac{\mathrm{a} \times \mathrm{b} \times \mathrm{c} \times \mathrm{d} \times \mathrm{e} \times \mathrm{f}}{6}}$

where $\mathrm{A}=$ geomorphology, $\mathrm{B}=$ shoreline erosion rate $(\mathrm{m} / \mathrm{yr}), \mathrm{C}=$ coastal slope $(\%), \mathrm{d}=$ mean significant wave height $(\mathrm{m}), \mathrm{e}=$ mean tidal range $(\mathrm{m})$ and $\mathrm{f}=$ relative sea level rate $(\mathrm{mm} / \mathrm{yr})$.

Finally, geospatial technology i.e. GIS and remote sensing techniques were applied to identify areas that are vulnerable based upon the weighted of the vulnerability of each variable. By identifying areas connected with vulnerability in a map form, it will contribute to the process of planning to prevent coastal erosion at the regional level.

\section{Results and Discussion}

\subsection{Geomorphology}

The geomorphology variable can be classified based on the type of landform at the shoreline. Geomorphology involves the type of sediments at beaches, type of cliffs, oceanic water bodies, and the depositional and erosion activity in the coastal area [14]. Rocky cliffs for example, represent that maximum resistance and low risk of coastal vulnerability. $87 \%$ of the shoreline is sandy and closely half of shoreline is eroding [15]. Pahang coastal sectors can be classified into three sectors: the offset coast in the north, the delta coast in the central area and the spit coast to the south. A long section of sandy beaches dominates the mainland coast and the coast of Tioman is rocky. The coastline of Pahang state indicates overall direction trends of 100 , and 1550 , to the north of Kuantan and between Kuantan and Kuala Pahang respectively, whereas the south of Kuala Pahang the coastline mostly tendencies to 1800 .

\subsection{Shoreline Change Rate}

The shoreline is frequently dynamic, as it involves erosion and accretion processes, as a result of the action of natural processes such as sea level rise, wave energy and sedimentation and human activity. The data used in this research was acquired from SPOT 5 satellite with $2.5 \mathrm{~m}$ spatial resolution and different temporal resolution. The images were digitized into line shape file format. The vector layers map of 2014 and 2006 were overlaid using ArcMap GIS software and final map was produced. RS data analysis for these periods showed that most of the areas experience significant erosion. Out of 10 stations selected for the analysis, 5 erosion sites and 6 accretions sites were identified. The total area of erosion was 142.9 ha and the accretion was 8.3 ha as shown in Table 2 . 
Table 2: The location of erosion and accretion along Pahang Coastal

\begin{tabular}{|c|c|c|c|c|c|c|}
\hline $\begin{array}{c}\mathrm{St} \\
\mathrm{n}\end{array}$ & Location & $\begin{array}{l}\text { Length } \\
\text { of erod- } \\
\text { ed } \\
\text { Shore- } \\
\text { line (m) }\end{array}$ & $\begin{array}{l}\text { Shore- } \\
\text { line } \\
\text { Change } \\
\text { (m) }\end{array}$ & $\begin{array}{l}\text { Ero- } \\
\text { sion } \\
(\mathrm{Ha})\end{array}$ & $\begin{array}{l}\text { Accre- } \\
\text { tion } \\
(\mathrm{Ha})\end{array}$ & $\begin{array}{l}\text { Ero- } \\
\text { sion } \\
\text { Rate } \\
(\mathrm{m} / \mathrm{yr})\end{array}$ \\
\hline 1 & $\begin{array}{c}\text { Pantai } \\
\text { Cherat- } \\
\text { ing }\end{array}$ & 584.9 & 42.0 & 0.2 & 0.1 & 2.9 \\
\hline 2 & $\begin{array}{l}\text { Legend } \\
\text { Villa } \\
\text { Resort }\end{array}$ & 930.0 & 14.9 & 0.1 & 2.8 & 1.8 \\
\hline 3 & $\begin{array}{l}\text { Sungai } \\
\text { Ular }\end{array}$ & 879.6 & 12.6 & 0.5 & 0.2 & 3.3 \\
\hline 4 & $\begin{array}{l}\text { Pantai } \\
\text { Balok }\end{array}$ & 5346.5 & 109.6 & 26.8 & - & 13.5 \\
\hline 5 & $\begin{array}{c}\text { Kelab } \\
\text { Golf } \\
\text { Pahang }\end{array}$ & 858.2 & 716.3 & 3.7 & - & 17.9 \\
\hline 6 & $\begin{array}{l}\text { Taman } \\
\text { Gelora }\end{array}$ & 531.4 & 116.7 & 2.5 & - & 14.4 \\
\hline 7 & $\begin{array}{l}\text { Pantai } \\
\text { Sepat }\end{array}$ & 1317.7 & 76.3 & 7.7 & - & 9.4 \\
\hline 8 & $\begin{array}{l}\text { Sungai } \\
\text { Penor }\end{array}$ & 1249.3 & 207.7 & 1.2 & 1.0 & 6.1 \\
\hline 9 & $\begin{array}{l}\text { Kam- } \\
\text { pung } \\
\text { Cherok } \\
\text { Paloh }\end{array}$ & 1062.2 & 118.7 & 5.5 & 0.3 & 14.6 \\
\hline 10 & $\begin{array}{c}\text { Tanjung } \\
\text { Agas }\end{array}$ & 1585.4 & 169 & 94.7 & 0.9 & 20.9 \\
\hline & Total & 14345.2 & & 142.9 & 8.3 & \\
\hline
\end{tabular}

The accretion shoreline rate with the high value of 1.0 ha generally occurred at Legend Villa Resort. Areas of Pantai Cherating, Legend Villa Resort, and Sungai Ular experience the minimum amount of shoreline eroding between 0.2 ha to 0.5 ha. Whereas, Pantai Balok, Kelab Golf Pahang, Taman Gelora and Pantai Sepa indicate no accretion process along the shoreline for this period The high value of erosion rate for eight years is Pantai Balok and Tanjung Agas with 26.8 and 94.7 ha respectively. The changes pattern of shoreline for both areas indicated that active process of erosion and accretion occur at these sites. Assessment of coastal vulnerability for these areas showed of that, the accretion process is considered less vulnerable, as they result in the addition of land areas towards the ocean. Besides, in [9] mentioned that eroding process is considered highly vulnerable if the resulting loss of natural as well as man-made resources associated with it.

\subsection{Land Use Area of Pahang}

Based on classification method, the land use and land cover pattern of shoreline along the Pahang coastal have changed within 8 years period of 2006 until 2014. Based on in-situ observation, the main land use and land cover (LULC) that exists along Kuantan to Pekan shoreline is an agricultural sector. The second dominan land use pattern is urban and commercial areas especially in the Kuantan city. District of Kuantan to Pekan is a quite less developed area except for Kuantan town at the north [2]. The finding is consistent with the study by Jabatan Perhutanan Negeri Pahang, which JPS mention that shoreline Pahang has a total of 2,600 hectares of reserved mangrove forests. Mangrove habitats were distributed in protected areas over 6 major rivers namely Sungai Kuantan, Sungai Bebar, Sungai Miang, Sungai Pontian, Sungai Rompin, Sungai Pahang Tua, Sungai Penor and Sungai Endau. Furthermore, in [16] found that small remains were also detected scattered in Sungai Chendor, Sungai Dua, Sungai Kempadang, Sungai Ular, Sungai Balok and Sungai Cherating.

Therefore, LULC is important to recognize the classes of LULC in a particular region and its assist in increasing the vulnerability of an area especially related to carbon dynamics, climate change, hydrology and biodiversity [17].

\subsection{Coastal Slope}

Among CVI parameters, the coastal slope is an important component that reflects the topographic slope of the coastal area. The value of the coastal slope can be determined by beach profile measurement using Abney level, total station and GPS. In case of the steeper coast, the impact of sea level rise would be insignificant, contrary to the flat coastal slope, where any increasing in sea level would be submerged on the land [18-19]. Based on in-situ measurement, all the location was determined the feature profile using the Beach Profile approach. The research study also found that the slope of coastal can determine using Google Earth software. The relationship of coastal material and slope of coastal is shown in Table 3.

Table 3: The relationship between type of coastal material and the slope of coastal

\begin{tabular}{|c|c|}
\hline Type of coastal material & Slope of coastal \\
\hline Very fine sand & $1^{0}$ \\
\hline Fine sand & $3^{0}$ \\
\hline Medium sand & $5^{0}$ \\
\hline Coarse sand & $7^{0}$ \\
\hline Very coarse sand & $9^{0}$ \\
\hline
\end{tabular}

\subsection{Sea Level Rise}

Sea level change reveals a complex and dynamic interaction between regional and global contributions from land and ocean processes $[20,21]$.The variable of relative sea level change naturally includes land change subsidence and tectonic motion [22]. In [1] reported that sea level change was recorded and monitored from 21 tide stations by the Department of Survey and Mapping Malaysia (JUPEM). The findings from analysis indicated clearly using long term recording of tide reading at Malaysia coastline area from tidal stations. The sea level rise can be assessed by multiplying the SLR rate estimate by the period. For example, the study about impact of climate change on SLR in Malaysia on 2010 by NAHRIM using linear trend analysis and satellite altimeter data, show that sea level rise along coastal of Peninsular Malaysia is in the range of 0.066 to $0.141 \mathrm{~m}$ in the year 2040 and $0.253 \mathrm{~m}$ to $0.517 \mathrm{~m}$ in the year 2100 respectively. Based on the current research, Tanjung Gelang indicates the maximum level of SLR with an increase of $14.42 \mathrm{~cm}$ and $32 \mathrm{~cm}$ in the years 2050 and 2100 respectively. Other studies also reported that SLR phenomenon may rise about $0.2 \mathrm{~cm} /$ year, although the small increase in sea level will have a devastating effect. The result in Table 4 for example, was contradicted by the experiments of who conducted by $[3,23]$.

Table 4: A Comparison Future Sea Level Rise in the current study for prediction on year 2050 and 2100

\begin{tabular}{|c|c|}
\hline Research Observation & Tidal Stations: Tanjung Gelang \\
\hline Current Study (2050) by [23] & $14.42 \mathrm{~cm}$ \\
\hline SLR Prediction on year 2050 & $11.09 \mathrm{~cm}$ \\
\hline Current Study (2100) by [23] & $32.00 \mathrm{~cm}$ \\
\hline SLR Prediction on year 2100 & $24.29 \mathrm{~cm}$ \\
\hline
\end{tabular}

\subsection{Mean Significant Wave Height}

In [24] explained that wave is mostly made by the wind travels on the sea surface. Heights of the waves depend on the property of the wind responsible for producing those. It is can be clear as the average height of one-third waves in a wave spectrum of time period [25, 17]. Significant wave height (SWH) is used an alternative to wave energy and is important in studying the vulnerability of shorelines. The wave climate is strongly influenced by the monsoons. The East Coast of Peninsular Malaysia is exposed to higher waves generated from the South China Sea, whereas the Straits of Malacca is sheltered by Sumatra Island on the West, thus wave height at the west coast of Peninsular Malaysia is lower [26, 1]. Based on the Malaysian Meteorological department (MMD), 
the recorded reading of wave height is usually less than $1.8 \mathrm{~m}$ and wave period less than 6 seconds during the Northeast Monsoon. On the other hand, wave height might be above $1.8 \mathrm{~m}$ with periods generally less than 6 seconds as shown in Figure 2 during the Southwest monsoon.

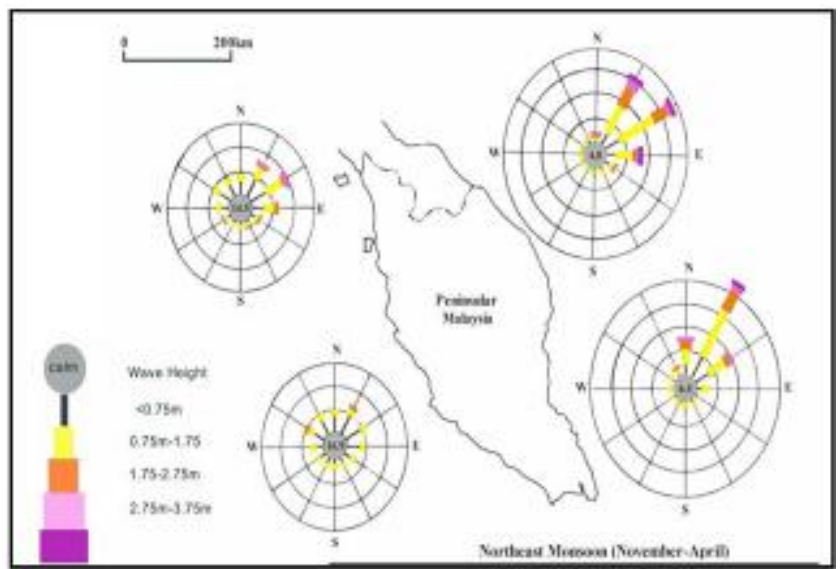

Fig. 2: The wave height during the Northeast Monsoon in Malaysia

\subsection{Mean Tidal Range}

Tide is a natural phenomenon caused by sea level to continually change over time as the resultant from gravitational attractions from the sun and the moon. During full moon and new moon, the highest tidal range happens due to the maximum difference between high and low tides. Regarding to [9], the mean tide ranges at the peninsular Malaysia show small value, up to $2.7 \mathrm{~m}$ in the Straits of Melaka and less than $2 \mathrm{~m}$ on the east coast. The highest astronomical tide was indicated around $1.8 \mathrm{~m}$ at Tanjung Gelang station and the highest values around $2.7 \mathrm{~m}$ representing in Sabah and Sarawak. Therefore, Port Klang in Selangor and Pekan in Pahang have represented a greater tidal range for the west coast and east coast of Peninsular Malaysia respectively [27, 28].

\section{Conclusion}

CVI can provide awareness towards the relative potential coastal damage due to future sea level rise. The shoreline of Peninsular Malaysia is extremely vulnerable to the natural processes such as wind, tidal, sea level and others. CVI method is to be used as an assessment for coastal vulnerability with seven types of proposed physical variables namely geomorphology, coastal slope, shoreline change rate, mean significant wave height, mean tidal range, relative sea level rate and land use. Based on results, the coastal index based methodology was recognized for calculating and evaluating the physical vulnerability that has been verified by many authors and has confirmed to be used for coastal and many developing regions because it is a quite simple method. Furthermore, the results from vulnerability maps provide guidance for local mitigation of threats in order to well organize and protection in the future development, especially along of shoreline.

\section{Acknowledgement}

The authors greatly acknowledge Earth Observation Centre, Institute of Climate Change, UKM and relevant agency such as NAHRIM in providing the information and field data. This work was supported by Research Fund (AP-2015-009, TRGS/1/2015/UKM/5/1 and TRGS/1/2015/UKM/5/3) by Research University Grants from Universiti Kebangsaan Malaysia and Ministry of Higher Education, Malaysia.

\section{References}

[1] Mohamad, M. F., Lee, L. H. \& Samion, M. K. H. 2014. Coastal Vulnerability Assessment towards Sustainable Management of Peninsular Malaysia Coastline. International Journal of Environmental Science and Development, 5(6), 533-538.

[2] Gornitz, V. 1991. Global coastal hazards from future sea level rise. Palaeogeography, Palaeoclimatology, Palaeoecology, 89(4), 379398.

[3] Jeofry, M. H. \& Rozainah, M. Z. 2013. General observations about rising sea levels in Peninsular Malaysia. Malaysian Journal of Science, 32(spec. iss.), 363-370.

[4] Faour, Ghaleb, Fayad, Abbas, Mhawej, M. 2013. GIS-Based Approach to the Assessment of Coastal Vulnerability to Sea Level Rise : Case Study on the Eastern Mediterranean. Journal of Surveying and Mapping Engineering, 1(3), 41-48.

[5] Wdowinski, S., Bray, R., Kirtman, B. P. \& Wu, Z. 2016. Increasing flooding hazard in coastal communities due to rising sea level: Case study of Miami Beach, Florida. Ocean and Coastal Management, 126, 1-8.

[6] Nicholls, R.J., Cazenave, A., 2010. Sea-level rise and its impact on coastal zones. Science 328, 1517-1520

[7] El-Hattab, M. M. 2015. Improving Coastal Vulnerability Index of the Nile Delta Coastal Zone, Egypt. Journal of Earth Science \& Climatic Change, 06(08), 1-7.

[8] Sabah SA 2012. Development of Coastal Vulnerability Index for the Kingdom of Bahrain. Journal Earth Science Engineering 2: 228-236

[9] Gill, J. A., Anwar, A. M. \& Omar K., S. 2014. Towards the implementation of continuous coastal vulnerability index in Malaysia: A review. Jurnal Teknologi, 71(4), 1-10.

[10] Gornitz, V. M., Daniels, R. C., White, T. W., and Birdwell, K. R. 1994. The development of a coastal risk assessment database: Vulnerability to sea-level rise in the U.S. southeast. Journal of Coastal Research Special Issue No. 12: 327-338

[11] Hammar-Klose, E.S., \& Thieler, E. R. 2001. Coastal vulnerability to sea-level rise: a pre-liminary database for the US Atlantic, Pacific, and Gulf of Mexico coasts. U.S. Geological Survey, Coastal and Marine Geology Program. http:// http://pubs.usgs.gov/dds/dds68/.

[12] Malaysian Meteorological Department, 2009. Climate Change Scenarios for Malaysia (2001-2099). Scientific report. Kuala Lumpur: Ministry of Sciences, Technology and Innovation.

[13] Tawang, A., Ahmad, T. M. A., \& Abdullahi, M. Y. 2001. Stabilization of Upland Agriculture under El Nino Induced Climatic Risk: Impact Assessment and Mitigation Measures in Malaysia. Agriculture.

[14] Azid, A., Noraini, C., Hasnam, C., Juahir, H., Amran, M. A., Toriman, M. E., Kamarudin, A., 2015. Coastal Erosion Measurement along Tanjung Lumpur to Cherok Paloh, Pahang during the Northeast Monsoon Season. Journal Teknologi, 1, 27-34.

[15] Economic Planning Unit (EPU) 1985. National Coastal Erosion Study. Kuala Lumpur: EPU.

[16] Ibrahim, S. 1998. Implementing MTEN's Recommendation: Identification Mapping and Reclassification of East Coast Mangrove Forest Using Aerial Photography, Remote Sensing and Geomorphological Techniques. Agricultural Science, ii (Section 2), 241-243.

[17] Sohl, T., \& Sleeter, B. 2011. Role of Remote Sensing. Remote Sensing of Land Use and Land Cover.

[18] Rao, P. 1992. Some Studies on Wave Prediction in Indian Seas. Martens, D. 2012. An analysis of the physical coastal system in front of East Coast Park, Singapore.

[19] Redzwan, G., Abdul Halim, H., Alias, S. A., \& Rahman, M. M. 2014. Assessment of Heavy Metal Contamination at West and East Coastal Area of Peninsular Malaysia. Malaysian Journal of Science, 33(1), 23-31.

[20] Garrison, T. 2005. Oceanography: An Invitation to Marine Science. 5thed. Belmont, California: Brooks/Cole-Thomson Learning

[21] Fredolin T. Tangang, Liew Juneng, Ester Salimun, Kwan Meng Sei, Loh Jui Le \& Halimatun Muhamad. 2012. Climate Change and Variability over Malaysia: Gaps in Science and Research Information. Sains Malaysiana 41 (11): 1355-66.

[22] Cooper, M. J. P., Beevers, M. D., \& Oppenheimer, M. 2008. The potential impacts of sea level rise on the coastal region of New Jersey, USA. Climatic Change, 90(4), 475-492.

[23] Ami Hassan, M.D. and Kamaludin, M.O. 2009. Sea Level Change in the Malaysian Seas from Multi Satellite Altimeter Data. Postgraduate Seminar of Geoinformation Science and Engineering, Skudai, Johor, pp. $1-21$. 
[24] Church, J. A., Nichols, R., Hay, J. E., \& Gornitz, 2010. Ice and Sealevel Change. Civil Engineering, 153-180

[25] Ashok Kumar, K. Raju, N.S.N., \& Sanil Kumar, 2005. Wave Characteristics off Visakhapatnam Coast during a Cyclone. Annual Report. Goa, India: National Institute of Oceanography, Ocean Engineering Division.

[26] Suursaar, Ü. \& Kullas, T. 2009. Decadal variations in wave heights off Cape Kelba, Saaremaa Island, and their relationships with changes in wind climate. Oceanologia, 51(1), 39-61

[27] Mat Amin, A. R., Ahmad, F., Mamat, M., Rivaie, M., \& Abdullah, K. 2012. Sediment Variation along the East Coast of Peninsular Malaysia. Ecological Questions, 16(1), 99-107.

[28] Fazly Amri Mohd, Khairul Nizam Abdul Maulud, Othman A. Karim, Muhammad Afiq Ibrahim, Yannie Anak Benson \& Ahmad Khairi Abd. Wahab. 2018. Integration of Geospatial Method and Hydrodynamic Modelling to Study the Impact of Sea Level Rise on the Coastal Area. Jurnal Kejuruteraan, 30(1), 76-88. 